\title{
Excavations for the Upper Labor Dam Site, Brackenridge Park, San Antonio, Bexar County, Texas
}

\author{
I. Waynne Cox \\ Center for Archaeological Research \\ Edgar D. Johnson \\ Center for Archaeological Research \\ C. Britt Bousman \\ Department of Anthropology, Texas State University
}

Follow this and additional works at: https://scholarworks.sfasu.edu/ita

Part of the American Material Culture Commons, Archaeological Anthropology Commons, Environmental Studies Commons, Other American Studies Commons, Other Arts and Humanities Commons, Other History of Art, Architecture, and Archaeology Commons, and the United States History Commons

Tell us how this article helped you.

This Article is brought to you for free and open access by the Center for Regional Heritage Research at SFA ScholarWorks. It has been accepted for inclusion in Index of Texas Archaeology: Open Access Gray Literature from the Lone Star State by an authorized editor of SFA ScholarWorks. For more information, please contact cdsscholarworks@sfasu.edu. 


\section{Excavations for the Upper Labor Dam Site, Brackenridge Park, San Antonio, Bexar}

County, Texas

\section{Creative Commons License}

\section{(c) (1) \&}

This work is licensed under a Creative Commons Attribution-NonCommercial 4.0 International License 


\title{
Excavations for the Upper Labor Dam Site, Brackenridge Park, San Antonio, Bexar County, Texas
}

I. Waynne Cox, Edgar D. Johnson, and C. Britt Bousman

\author{
Robert J. Hard \\ Principal Investigator
}

Texas Antiquities Permit No. 1755

Ccopyright 1999

Center for Archaeological Research

The University of Texas at San Antonio

Archaeological Survey Report, No. 268 
The following information is provided in accordance with the General Rules of Practice and Procedure, Chapter 41.11 (Investigative Reports), Texas Antiquities Committee:

1. Type of investigation: Excavation

2. Project name: Upper Labor Dam

3. County: Bexar

4. Principal investigator: Robert J. Hard

5. Name and location of sponsoring agency: San Antonio Parks and Recreation Department

6. Texas Antiquities Permit No.: 1755

7. Published by the Center for Archaeological Research, The University of Texas at San Antonio, 6900 N. Loop 1604 W., San Antonio, Texas 78249-0658, 1999

A list of publications offered by the Center for Archaeological Research is available. Call (210) 458-4378; write to the Center for Archaeological Research, The University of Texas at San Antonio, 6900 N. Loop 1604 W., San Antonio, Texas 78249-0658; e-mail to car@lonestar.utsa.edu; or visit CAR's web site at http://www.csbs.utsa.edu/research/car/index.htm. 


\begin{abstract}
Upon notification, in 1995, that a portion of a Spanish Colonial acequia had been exposed in Brackenridge Park, the Parks and Recreation Department of the City of San Antonio entered into a contract with the Center for Archaeological Research (CAR) of the University of Texas at San Antonio to investigate and document the structure. In September of 1996, a team from CAR, utilizing a backhoe and operator provided by Parks and Recreation, began a limited investigation of the structure. The structure proved to be the dam for the Upper Labor and displayed two distinct construction periods, Spanish Colonial and post-1860. It was further documented that the structure acted as a diversion device rather than a full empoundment structure.
\end{abstract}




\section{Contents}

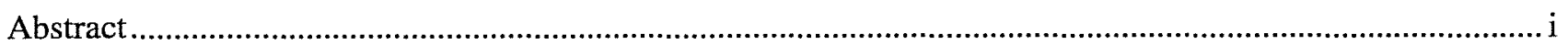

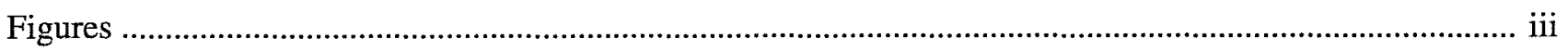

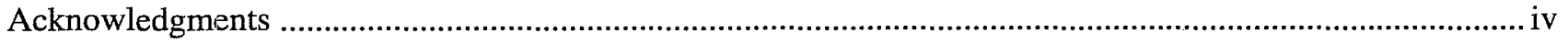

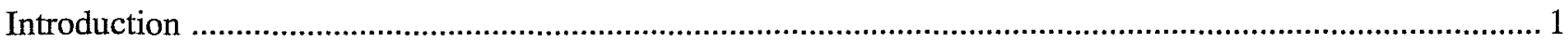

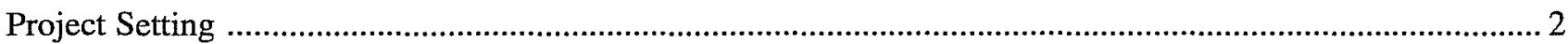

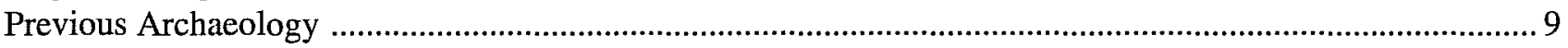

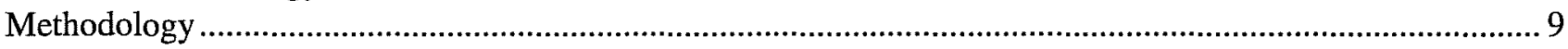

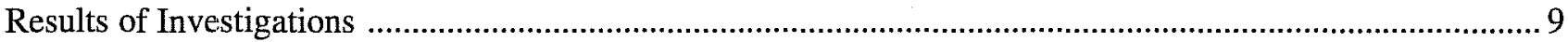

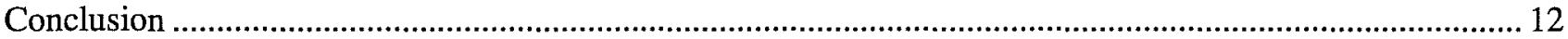

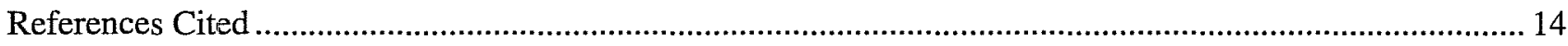

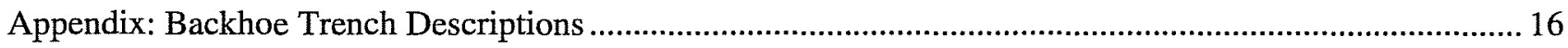




\section{Figures}

1. Route of the Upper Labor Acequia ..................................................................................................... 1

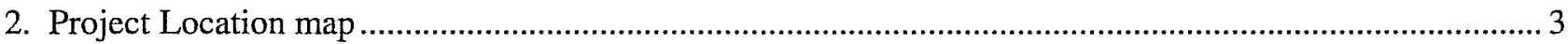

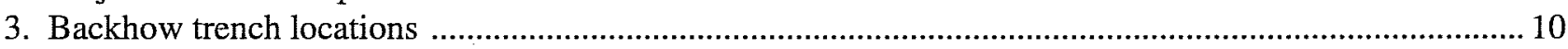

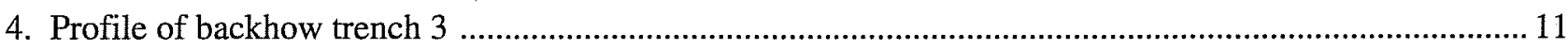

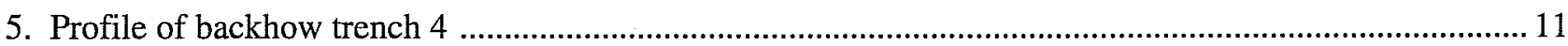

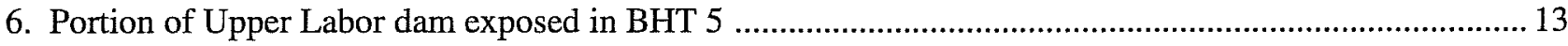

7. Upper Labor dam stonework …………………………..................................................................... 13 


\section{Acknowledgments}

The authors must initally recognize the perception of Steve Tilloson, an architect with Kell Munoz Wigodsky, who first discovered that a hewn limestone structure exposed by heavy rains was the Upper Labor dam. His observation allowed the Parks and Recreation Depatement to call in advisors from the CAR and the City of San Antonio Office of Historic Preservation to confirm the find and develop recommendations for documentation. Ann McGlone opened the files of her office, and her assistant Clinton M. McKensie rendered both archival assistance and hands on work in the trenches. Additional research was also provided by Dixie Watkins III and Kevin Young. Without the assistance of the personnel of the Parks and Recreation Department, their support and equipment, this project could not have been accomplished. CAR illustrator Bruce Moses provided the maps

essential for this report, and the editorial expertise of William Bishel provided the professional touch required for publication. 


\section{Introduction}

The Upper Labor Acequia (Acequia de Labores de Arriba), last of the Spanish Colonial irrigation systems, was begun in July 1776 to provide irrigation for 600 acres of land between the old quarries and the San Antonio River (Figure 1). Completed by March 10, 1778, it provided water to some 50 tracts of land for the residents of the villa of San Antonio de Béxar. The dam was constructed just below the head waters of the San Antonio River to raise the level of the water and allow it to flow into the ditch constructed approximately along the route of St. Mary's Street, then around Tobin Hill to a point south of San Pedro Springs, where it crossed the San Pedro acequia, the source of the municipal water supply for the villa. It then returned the surplus to San Pedro Creek.

In 1875, the Upper Labor was modified to function as the initial portion of the new Alazán ditch. The Alazán departed the old channel below San Pedro Park, passed over the springs, proceeded down the right-of-way of the Missouri-Pacific Railroad to Frio Street, and discharged into Alazán Creek on the city's southwest

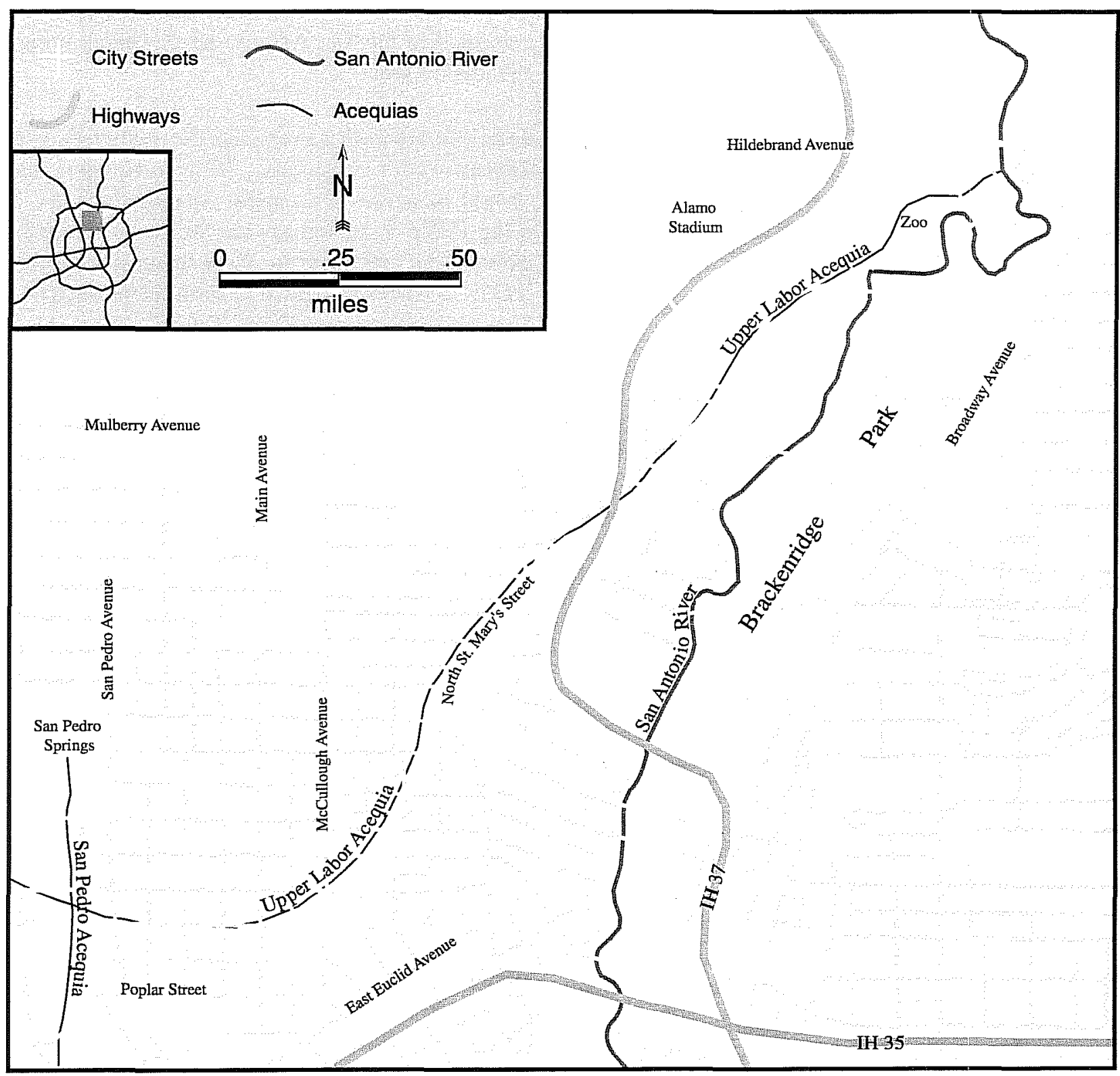

Figure 1. Route of the Upper Labor Acequia.. 
side. While it served to irrigate some of the lands west of San Pedro Creek, its primary purpose was to convey flood waters away from the Olmos Creek and away from the downtown area. While the Alazán portion was closed in 1896, the Upper Labor continued to function for a few more years. It was finally closed shortly after the turn of the century although a small portion of the acequia still functions as part of the water fowl display area in the San Antonio Zoo.

Following a particularly heavy rainstorm in 1995, a local architect noted that hewn stone was exposed in a small washout beside the San Antonio River in Brackenridge Park. Realizing that this might be the now forgotten Spanish Colonial dam, the Parks and Recreation Department of the City of San Antonio entered into a contract with the Center for Archaeological Research (CAR) of the University of Texas to investigate and document the structure. In September of 1996, a team from the CAR, utilizing a backhoe and operator provided by Parks and Recreation, began a limited investigation of the structure.

\section{Project Setting}

The site of the excavation is in the extreme northern portion of Brackenridge Park to the east of Park Headquarters immediately south of Hildebrand Avenue. (Figure 2) The area is situated on the west terrace of the San Antonio River below the springs which served as its source, and below the confluence of the river and Olmos Creek. Primarily composed of Trinity and Frio soils the low-lying flood plain provided a natural ford of the river for early travelers (Taylor et al. 1966). A small pond, currently serving as a landscape feature, is impounded by an earth berm which serves as a small picnic area with tables and cooking grills.

\section{A Brief History of San Antonio}

"It was water-cool, abundant, life-giving - that first drew men to the San Antonio Valley" (Ramsdell 1959:9). The waters that flowed so abundantly from the numerous springs have created an haven for man that has sustained life since the arrival of the earliest people to the area. It was this same lush, watered environment that prompted the Spanish to establish a presidio and mission in the valley to serve as a supply station to support their settlements in East Texas. On May 1, 1718, Father Antonio de San Buenaventura Olivares established the Mission San Antonio de Valero (The Alamo) below San Pedro Springs. Four day later, Governor Don Martín de Alarcón founded the Villa de San Fernando de Béxar (Castañeda, 1936:92). A second mission, Mission San José y San Miguel de Aguayo, was established in 1720 by Father Antonio Margil. The abandonment of the East Texas settlements in 1731 caused their missions to be relocated to the San Antonio River valley, bringing the total to five.

In an effort to further strengthen the frontier, Brigadier General Pedro de Riveria y Villalón believed that it should be settled with stable Spanish families, and King Philip V looked toward the Canary Islands to provide the emigrants for New Spain. On March 9, 1731,56 Islanders arrived to form the nucleus of the first civil settlement of Texas (Chabot 1937:141). The water that has attracted them now had to be channeled into the fields to help produce the crops to sustain this growing community on the far edge of New Spain. An acequia was constructed for each of the missions and one to serve the civil community. These waterways would set the pattern of growth for the community and serve it for over a 100 years.

With the beginning of the nineteenth century, a movement for independence and freedom began to rise throughout the Americas. In January 1811, the revolution started in Mexico by Father Miguel Hidalgo spread to San Antonio. Juan Bautista Casa, in charge of the presidial troops of Béxar, declared himself as head of government and claimed allegiance to Hidalgo. His disorderly administration was overthrown on March 2. In March 1813, the city was captured by the forces of the Republican Army of the North and Texas was declared an independent republic. This insurrection was rapidly defeated on August 18 by the Royalist army of General Joaquin de Arredondo south of the Medina River. Arredondo exacted a swift and drastic retribution with hundreds imprisoned or executed. 


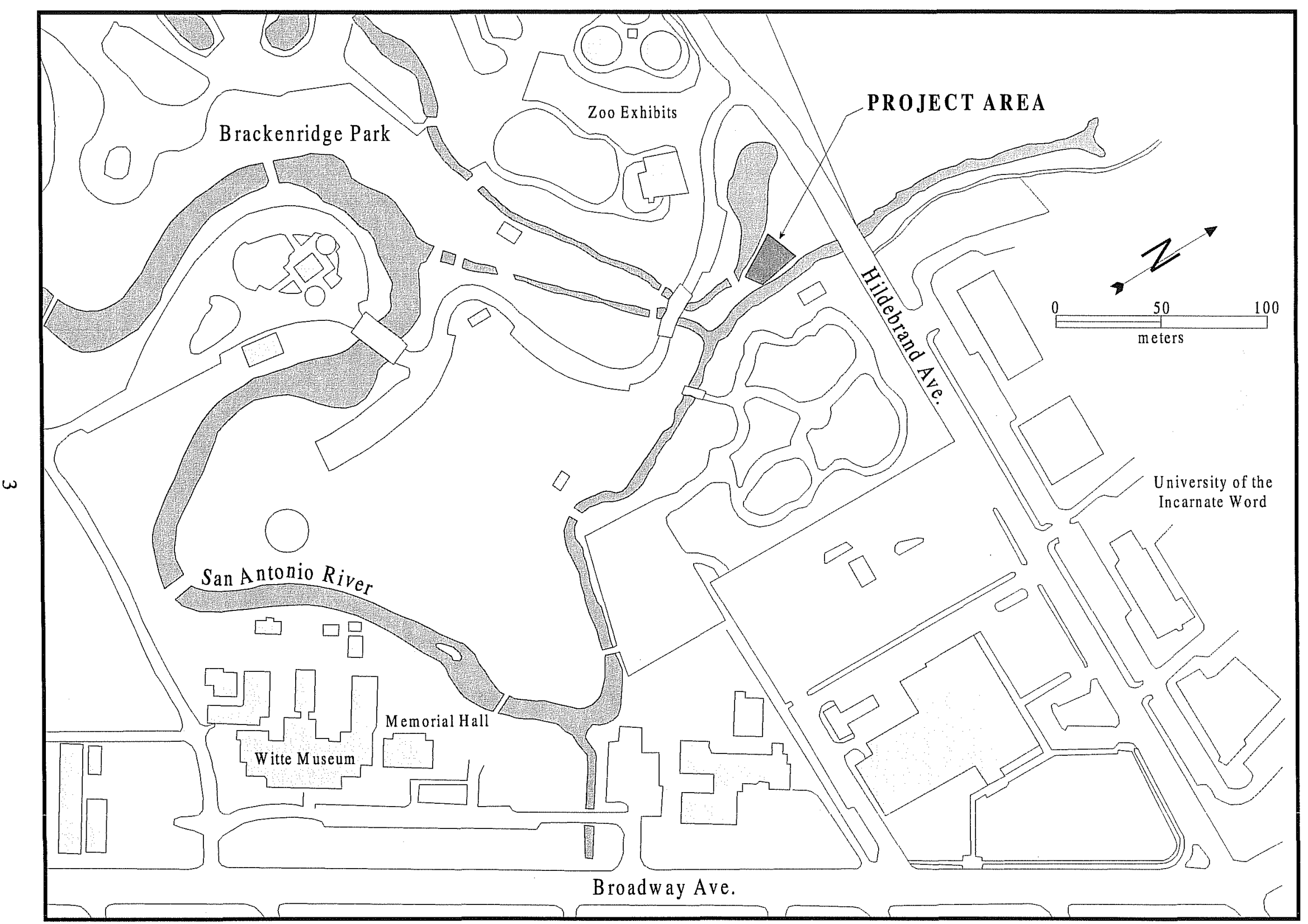

Figure 2. Project location map. 
San Antonio was left a shambles, the property of the citizens confiscated, and the majority of the men either dead or having fled the country (Cox 1992:6). The frontier was left devastated and virtually deserted. The decline in population was so severe that a Spanish inspector, Juan Antonio Padilla, recommended that all confiscated properties be restored to encouraged the return of the exiles (Hatcher 1919:69) In December 1820 , a partial solution was offered by Moses Austin's request for authority to bring a colony of AngloAmericans to Texas. Other impresarios followed and a steady influx of immigrants was introduced into eastern Texas. While this had the effect of repopulating the frontier, it created an enclave with little loyalty or dedication to the Mexican state (Castañeda 1926:261) This soon lead to open war with the Mexican government and the creation of the Republic of Texas in 1836. A decade of tumultuous times followed with the entry of Texas into the United States in 1846 , leading to the Mexican War.

The city maintained its positions as the largest city in the state but experienced little dynamic growth amid the constant struggles of wars and the demands of life on the edge of the frontier until after the end of the Civil War. By the mid-1870s, San Antonio stood as the only major city in the United States not serviced by a port or railroad. On February 19,1877, the long awaited arrival of the Galveston, Harrisburg and San Antonio Railroad became a reality. The Express newspaper exclaimed "...yesterday the people of San Antonio celebrated the completion of our first railroad and the inauguration of the running of regular passenger trains, events that properly take rank high among the most important events connected with the entire history of the city" (San Antonio Express [SAE], 20 February 1877). The growth surge that accompanied the arrival caused the city to realize that they must progress and enter the new century. Within a year the city completed its municipal waterworks, and the city was no longer totally dependant upon the old acequias ( $S A E, 10$ July 1878)

\section{A History of the Upper Labor Acequia}

The selection of the lush valley of the San Antonio River for the site of a mission and presidio was unquestionably due to the abundance of natural springs in the area. The rich land offered fruits, herbs, and game along the banks of its river and creeks (Tous 1930:48-49). The wealth of land on the frontier was directly limited in its value by the availability of water, for only irrigable land would reliably produce in this semi-arid environment. When the Presidio of San Antonio de Béxar was founded in 1718, the land was farmed communally to enable the garrison to establish some degree of self-sufficiency. With the arrival of the Canary Islanders in 1734, Captain Almazán was forced to dispossess the original tenants and distribute the irrigable lands to the newly established civil settlement. Because they were the King's representatives, 10 of their number had received life appointments to govern the villa. The only non-Isleño in a position of authority was the captain of the presidio, who served as the justicia mayor, or senior magistrate (Poyo 1996:5).

In 1745, the 49 families of Béxar that were not Islanders petitioned the viceroy for access to land and water. Although their petition received a favorable response, Governor Francisco García Larios failed to act (de la Teja 1995: 75-80). This was, no doubt, because it was not favored by the Islanders, who found that their control of the irrigated lands had given them an economic advantage. In August 1762, a group of 13 citizens petitioned the governor, Angel Martos y Navarrete, for the land and water to be distributed as had been previously ordained. In their request, they claimed that "about the year of forty-five" the viceroy had ordered this of his predecessor, but for reasons unknown, he had failed to comply. The governor agreed that the request was valid and directed Geronimo Flores, who was "skillful in withdrawing water," to measure the lands proposed for the acequia. Flores reported that a channel could be constructed from a point on the river 5853 varas $(5 \mathrm{~km})$ north of the villa that would pass through 5000 varas $(4.2 \mathrm{~km})$ of irrigable land. The only obstruction that presented itself was a stretch of 150 varas $(126.9 \mathrm{~m})$ "across the brow of the hill which is called 'Loma de la Viejá", (now Tobin Hill). He further noted that it would require a dam of 35 varas $(29.6 \mathrm{~m}), 25$ of them two and threequarters varas in height $(2.3 \mathrm{~m})$ and the remaining fifteen $(12.7 \mathrm{~m})$ of one and one-half varas $(1.3 \mathrm{~m})$. He estimated the cost of the dam and canal at three thousand pesos (Bexar Archives Translations, 
"Petition and Decree, August 16, 1762". Volume 36, Reel 5, Frames 27-35. Microfilm Collection, John Peace Library, The University of Texas at San Antonio). The governor fully agreed with the proposal and submitted it to the viceroy, but due to a lack of appropriated funds, the plan was not put into effect.

Fourteen years later, the citizens would again petition the new governor, Juan Mariá, Baron de Ripperda, for the additional land and water. The reason for this renewal of interest may have arisen from the fact that the villa was in the throes of a severe drought which began in 1771 and lasted for six years (Gunn et al. 1982:70). The governor, well aware of the volatile nature of the various factions within the villa, approached the proposal with diplomatic skill. On January 10,1776 , he addressed the citizens of the villa, stating that "there will be found in the archives of this province, two orders from the Sir Viceroy Marquez de Casa Fuente, of December 10, 1731 and March 12, 1733 , distributing the waters of the two springs of San Pedro and San Antonio and that of the five missions adjoining this presidio and village." He then noted that the governor, Antonio Bustillos, commissioned Lieutenant Governor Matheo Perez to give possession of a saca de agua above the Paso de Tejas out of the San Antonio River to the residents of the village on October 27, 1733 (Spanish Archives [SA], Original in Bexar County Archives, Office of the County Clerk, Bexar County Courthouse, San Antonio. Volume 3:317). He requested that "all Canary Island settlers as well as all the rest of the inhabitants . . . in order to avoid in future all motives of discord" present any documents that "may prove in their favor" within four days (Corner 1890:46). Upon receiving no valid complaints from this quarter, he addressed a similar letter to Fray Pedro Ramires, president of the missions, inquiring if this would adversely impact the missions. The padre replied that he did not think that the missions would be injured by the building of the ditch ( $S A$, Volume 3:318)

Having satisfied himself that neither the villagers nor the clergy had a strong protest against the project, he ordered that by January 29,1776, all "resident Islanders and others present themselves before me, and those who wish to contribute to said ditch, therefore after having enlisted themselves, to commence same, each to commence with one peon and the necessary tools" (SA, Volume 3:319). He then specified that distributions of the lands would be made by suertes with its corresponding one day of water to each of the participants. The construction of the ditch was to be placed in charge of an "able man of experience" (SA, Volume 3:321). The shareholders met on July 13, 1776, and elected Angel Galin to supervise the four peon and 26 men "who are to work daily on said ditch." Thoribio Fuentes was placed in charge of the actual construction. For this they agreed to pay Galin one peso per day "until the madre and other necessary ditches" were finished and Fuentes was allotted an additional portion of land (SA, Volume 3:322-324).

By April 28, 1777, the acequia had reached the midpoint of its construction. In order to place the ditch in operation for the planting season, the ditch was returned to the river, and a drawing was held to distribute the first 26 suertes, containing some 2,530 varas $\left(653 \mathrm{~m}^{2}\right)$ of land. The governor then called all officials of the presidio, missions and villa together for the drawing of the suertes. The names of the shareholders were placed in a brass urn and sealed. The numbers of the suertes where placed in a like urn and sealed, and "two boys of tender age" proceeded to draw one ticket, alternately, from each urn to select the property holders (SA, Volume 3:325-326).

By March 1778 , the remaining portion of the acequia was finished, "draining into the San Pedro Creek by a trough ... so that the residents located on the other side may avail themselves of its excess." The drawing procedure was repeated to distribute the remaining suertes of land. One exception was that Francisco Xavier Rodriquez did not take part in the drawing for he had agreed to take a suerte and one half to the north of the ditch (SA, Volume 3: 327). Thus by March 10, 1778 , the acequia was complete and the remaining irrigated portions of land had been distributed.

The acequia was apparently constructed as originally envisioned by Geronimo Flores in 1762 . The dam was erected on the west bank of the river at the "Paso de Tejas," now Hildebrand Avenue, supplied by the group of springs to the west of the main spring feeding the river. The first portion, constructed between July 1776 and April 1777, progressed along the contours toward 
the southwest to a point at the present intersection of Evergreen Court and North St. Mary's Street. It returned to the river near the intersection of St. Mary's and Ninth streets. The final segment, constructed the following year, extended the acequia below the brow of Tobin Hill (Loma de la Viejá) toward the southwest to near the intersection of Main Avenue and Bethel Street. From here, it followed the contour of the hill toward the northwest, crossing the San Pedro acequia on an aqueduct near Cypress and La Harpe Street, and returned its waters to San Pedro Creek. These additional irrigated lands were divided into 26 long, narrow tracts between the acequia and the San Antonio River. Although the farm was officially named $N u e s t r a$ Señora de los Dolores (Our Lady of Sorrows) it was generally referred to as the Labores de Arriba (Upper Labor).

The operation of the acequia is explained in an Auto, or edict, from Governor Domingo Cabello. "Beginning on the twelfth day of January and thereafter, the work of reinforcing the enclosures be undertaken in common, and that the rest of the year each individual partner is to take care to repair the water gates and whatever deterioration may occur in the part that belongs to him" (Bexar Archives [BA], "Petition and Auto, March, 1784" Center for American History, The University of Texas at Austin, Microfilm Reel 15, Frames 0967-0973). He further ordained that after the third of February, the cleaning and repairs on the main ditch were to begin "so as to facilitate irrigation to prepare the land for sowing early corn, cane fields, and gardens."(BA, "Petition and Auto, March, 1784"). This schedule of procedure was maintained throughout the use of the acequia, a period of well over 100 years. It was by compliance with this maintenance schedule that the system was kept in operation and insured an adequate and proportional share of water for all the fields.

During the troubled times of the Mexican Revolution, the acequia systems were badly neglected and fell into a devastating state of disrepair. As the city began to expand toward the newly opened public lands to the north, the problem became critical and it was recognized that an adequate flow of water to the lands was necessary. In November 1857 , the City Council resolved "that the city surveyor be required to examine the old irrigation ditch for the Upper Labor with the view of reopening the same, and report to the board at its next meeting as to the practicability and probable cost of reopening the same, and give his written opinion as to the best mode of reopening the same." (City Council Minutes [CCM], Volume C:95. Office of the City Clerk, City Hall, San Antonio, Texas).

In December 1860, W. H. Wetherby, a resident of the Upper Labor brought to the attention of the council the stoppage of the water in the Upper Labor Ditch. He proposed to reopen the ditch and insured the flow "of the water from one end to the other" for $\$ 75.00$ (CCM, C:276). However, Council recognized that cleaning and minor repairs were only temporary measures; therefore, in January 1862, the Mayor was authorized to "arrange with the city surveyor the dimensions of a new dam, etc., at the head of the Upper Labor ditch, and that the Public Improvements Committee and City Engineer have said work done to the best advantage" (CCM, C:340). The cost of these improvements was to be borne by the property owner of the land served by the ditch (CCM, C: 340). The extent of the work performed at this time is not recorded.

On March 26, 1865, a huge cloudburst to the north of the city filled Olmos Creek and the river to overflowing. The river rose to a height of 14 feet above normal in the central city area. It swept from its banks and devastated the entire business section, took two lives, left hundreds homeless and caused losses into the thousands of dollars (SAE, 13 December, 1913). The flood waters swept away the San José acequia dam and caused extensive damage throughout the system. Council appointed a special committee to investigate and give recommendations. Among their findings was a suggestion to divert more water from the city at the Upper Labor and Alamo ditch dams to prevent it from reaching the constricted river channel within the city (CCM, C: 475). Although no action was taken upon this suggestion at the time, it was not ignored. In 1867, the Council passed a resolution stating:

whereas it is believed by many citizens that the overflows of the San Antonio River are caused principally by the large amount of water, after 
heavy rains, flowing from the Olmos Creek, some five miles above the main square of this city, and whereas, it is believed by scientific men rises in said creek can be prevented by damming the Olmos and opening a canal from said Olmos Creek to the northeast branch of the Alazán Creek, which passes around the city and empties into the San Pedro Creek one mile and a half below the city; therefore, be it resolved that the city engineer be instructed to proceed and survey and level the land between the head of the northeast branch of the Alazán and the Olmos and make a report on the practicability of opening said canal, and whether the same, if opened, will prevent high rises in the San Antonio River. (CCM, C: 577).

In June 1868, city surveyor and engineer G. Freisleben presented a plan to Council, which was promptly referred to the Committee on Public Improvements. It would have been unlikely that any favorable comment would have been forth coming at that time, for at the same session Alderman Hertzberg charged that the city surveyor "whose disloyalty during the Rebellion is well known" was incapable of discharging his duties (CCM, C: 659). Freisleben was subsequently dismissed by Reconstruction military authorities and replaced by Cornelius Hartnett (CCM, C: 659).

The plan was delayed by funding and political action until January 1872 . Hartnett presented a proposal for a ditch originating at a new dam just above the head waters at the confluence of Olmos Creek. It would then flow from a new ditch from the west bank, roughly parallel to the Upper Labor ditch, above the city rock quarries. It would pass a short distance above San Pedro Springs and turn south to join with Alazán Creek. The proposal was immediately challenged in that it would require too large a dam, a thirty-foot embankment and at least three new bridges (SAE, 2 February, 1872). The proposal was immediately tabled.

On November 12,1872 , a new mayor and city council were installed, and C. Hartnett was replaced by G. Freisleben (CCM, D:51). In 1874 council again began to consider the construction of the diversion to the Alazán, and the city engineer was instructed to resurvey the design. On June 2, Friesleben presented his evaluation to Council regarding to the "Hartnett Plan" for the Alazán Ditch. He found:

First, the line adapted is not favorable. The new ditch from the head of the Upper Labor Ditch down to North 13th Street on to the mouth of the proposed tunnel west to the San Pedro Creek is on a dead level for a distance of three and twothirds miles. Second, the plan is to raise the water in the upper part of the Upper Labor ditch four feet which would overflow a large part of the adjoining lands of G. W. Brackenridge. Without consent the whole plan is impracticable; the new channel just above the lower line of Brackenridge prevents raising of the water. Third, the raising of the water in the Upper Labor Ditch and the condition of the banks of said ditch give just cause of apprehension that breaks may occur which will not only endanger the new ditch but also destroy the irrigation in the Upper Labors. The owners of the lands in the Upper Labor are most interested parties in this new undertaking and I think the work should not be made without their full approval and consent.

Due to the distressing nature of his report, action was laid over until Mr. J. P. Hector could be consulted to produce another opinion on the subject (CCM, D:111). On July 23, the report of Mr. Hector on the Alazan ditch was received and read; after some discussion on the subject, the member of Council agreed to meet " to repair to the line of the survey of said ditch for the purpose of making a personal examination of the same" (CCM, D:118). After their inspection they accepted a report "with specifications from the City Engineer" and authorized the mayor to contract "for the making of said ditch, commencing at the San Pedro Avenue over the Upper Labor ditch, passing around the San Pedro Spring, from then running down into the Alazan near its juncture with the San Pedro" (CCM, D:118).

In order for the Upper Labor ditch to have the carrying capacity necessary to provide for adequate flow through the Alazán ditch, it was necessary to raise the level of the initial portion of the Upper Labor. On February 12, 1875, a contract was issued to the firm of A. Earhart, Millar and Riordan to perform the 
necessary work (CCM,D:147). This called for 600 perches of stone to be added to the east and west wall of the old channel, approximately $14,850 \mathrm{ft}^{3}$ of stonework. During the process of construction, a question of the quality of the work was raised before the Council. An inspection committee of Aldermen William Prescott and George R. Dashiel was appointed to examine the stonework. While they found that the stonework was improperly set, the mortar inferior and the level inconsistent, they placed the fault not upon the contractor, but instead, upon the Engineer for a lack of supervision (SAE, 5 May, 1875).

The flags flying over San Antonio had changed from Spain to Mexico, to Republic of Texas, to the United States, to the Confederacy, and back to the United States; yet the use of the acequias remained essentially the same. The same basic Spanish laws of irrigation remained in force, supported by the changing governments because they produced the most effective means of controlling and distributing the water. However, in the waning years of the 1890 s the acequias within the city no longer served the purposes for which they were designed. The farmland had changed to residential housing and the truck farms were now far to the south and west. Where the acequias had once been the sole source of drinking water for much of the city, this need was now supplied by a modern water plant. The channels had become expensive luxuries to water the gardens of the neighborhoods. New artesian wells, drilled deep into the Edwards Aquifer far beneath the city, now relieved the waterworks from its dependency upon the irregularities of the river and springs that had been the source for the acequias. This increased withdrawal from their source however, soon began to become apparent in the decreased flow of the springs that fed both the San Antonio River and San Pedro Creek.

In his annual report for 1894, Mayor Paschal observed that the Alazán no longer paid for its upkeep and recommended it be closed at the point where it separated from the Upper Labor ditch (CCM, K:258). Within only a few years the deteriorating conditions of the water level from the springs and the flow of the water in the ditches became a serious problem to those along their banks. In August the council was forced to pass an ordinance declaring that the Upper Labor ditch, from McCullough Avenue to its juncture with San Pedro Creek, was a public nuisance and should be closed (CCM, M:108; City Ordinance [CO] JM:80, Office of the City Secretary, City Hall, San Antonio). On 16 December 1896 the Ditch Commissioner was directed to cut off the water at McCullough (CCM $\mathrm{M}: 242$ ). The following January, an ordinance was introduced by Alderman Hoefling to require that the commissioner "flush the Upper Labor ditch to clean it before it is covered up." (CCM, M:245). Thus the Alazán portion of the ditch was closed, but the older section continued to operate in a limited fashion.

In July 1904, Alderman Barker presented the petition of various citizens concerning the sluggish condition of the San Antonio River. He pointed out that there were at present ten dams across the river within the city limits that were causing the river to silt badly. "Dr. Barker's report points out that there is now an average of six feet of mud and slush at the bottom of the river with ten feet up near the head and that this is artificial, as the river has a gravel bed of $21 / 2$ feet throughout its length in the city, and with the dams removed the river, as in former times, would flow boldly over its gravel bed." (San Antonio Light, 12 July, 1904). Alderman Salliway interjected that he did not see the use of swans sailing around, or the ducks and ducklings either for that matter. Barker then suggested that the matter be referred to the city engineer for survey ( $S A E, 12$ July, 1904). The engineer fully agreed with Alderman Barker "and believed if his suggestions were carried out it would be a great and everlasting benefit to the river and city at large." He did, however, suggest a change to reduce cost, he advocated a head gate in the old Alamo acequia dam, by which means a head of water could be maintained, or by opening it the river could be allowed its natural flow. He also recommended a gate in the "old Mexican dam," [Upper Labor dam] this would enable the city to keep any desired quantity of water in Brackenridge Park, or permit the river to flow." (SAE, 26 July, 1904).

The urban acequias were all closed, or their uses altered to drainage channels, because their cost had exceeded their usefulness. The Upper labor has been filled, and for the most part forgotten. Only traces of its limestone walls along the back property lines of a few residential areas mark its course. San Antonio 
residents and tourist have seen its most visible remains - a portion of the channel above the old Water Works ditch and a segment of the water fowl area within the zoo in Brackenridge Park-but few realize its historic significance.

\section{Previous Archaeology}

No archaeological excavations have been done in the area of the Upper Labor dam. At this time it is not known when the dam was covered, but during the Works Project Administration (WPA) period the headgate and a small portion of the stone lined channel was replicated in limestone. The primary source of information concerning the dam's history and location have come from archival records. However, a portion of the unlined Upper Labor ditch was observed and reported during a drainage project along North St. Mary's Street (Fox and Cox 1988). Additional investigations have been conducted on the Alazán addition to the acequia and have been reported in other CAR publications (Fox 1978, Labadie 1987, and Nickels and Cox 1996).

\section{Methodology}

Following the architect's observation of the exposed stone in Brackenridge Park, personnel from the city Historic Preservation Office and CAR were alerted and began investigation. Historic maps and other historical documents were consulted and indicated that the Upper Labor dam should be expected in this location. Since the earliest components of this dam were constructed during the Spanish Colonial period, investigation and documentation of the site were particularly significant. Because of prior commitments on the part of both Park's Department and CAR personnel, the site was stabilized and investigation delayed until a more opportune time. It was decided that the investigations should be limited to merely confirming the nature and extent of the remaining structure to facility future planning.

Therefore, the objectives of this investigation were (1) to verify the exact location of the Upper Labor dam (2) to define the physical boundaries of the dam; and (3) to ascertain how much, if any, of the original
Spanish Colonial component was still intact. It was recognized by all parties that only limited information was required at this time.

Detailed archival research was conducted in an attempt to obtain information regarding the design, construction and alteration of the dam, as well as its eventual abandonment. In the field, five backhoe trenches (BHTs) were excavated (Figure 3) and profiles were drawn and described showing stratigraphy and dam construction. As the initial pothole provided evidence on the location of the dam, the backhoe trenches were placed to assess the geological setting, function, and additional details on the location of the dam. It was unclear if the dam was a diversion dam or a retention dam. A small number of prehistoric artifacts and sediment samples were collected from the backhoe trenches. Due to the project's objectives and a two-day time constraint, no hand excavations were conducted. The city of San Antonio Parks and Recreation Department provided a Case $580 \mathrm{~K}$ backhoe and operator for the project.

\section{Results of the Investigations}

The initial goal was to establish a general geological context for the dam. Consequently, the first trench was not opened at the known area of the exposed stone, but on the eastern portion of the site. BHT 1 was located on the edge of the terrace and oriented roughly east-west to determine if the dam was set into the terrace (see Figure 3). No evidence of the dam was discovered in BHT 1, but a prehistoric site was discovered at this location. The geological efforts indicated that an alluvial terrace had formed, probably during the Late Holocene, and that this terrace contained evidence of a possible prehistoric site 120 $\mathrm{cm}$ below its upper surface (see Appendix for profile descriptions).

The location of the dam's eastern edge was still in question. Therefore, the crew decided to work back from the unknown areas south of BHT 1 toward the known location of the exposed stone. BHT 2 was south of BHT 1 and oriented on an approximate north-south axis (see Figure 3). An eight-inch water main was exposed. This pipe fed a fire hydrant located on the 


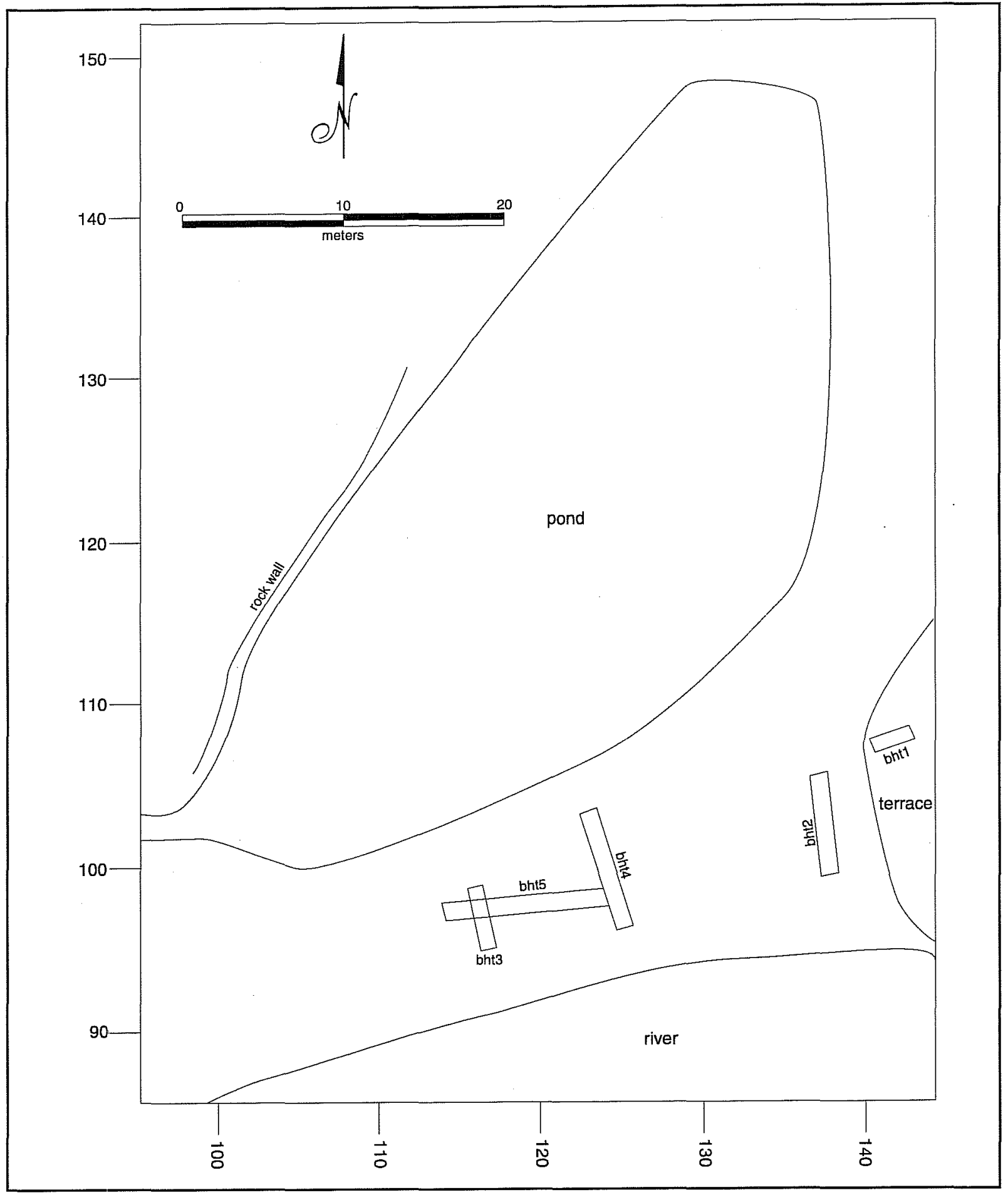

Figure 3. Backhoe trench locations. 
edge of the entrance road to the park. The sediments in BHT 2 show that an alluvial terrace deposit with prehistoric artifacts (three flakes collected from Zone 3) was truncated by erosion and a $44 \mathrm{~cm}$ thick dark gray to very dark grayish-brown clay loam was deposited over the truncated alluvial terrace deposit. This truncated terrace was the same terrace documented in BHT 1. The depth of prehistoric materials in both BHTs is similar and they may represent the same site. The upper $44 \mathrm{~cm}$ of deposits in BHT 2 probably represent more recent alluvial sediments and the significance of these sediments will be discussed below.

BHT 3 was opened at mid-line of the expected dam location on a north to south axis, about $3.5 \mathrm{~m}$ from the bank of the San Antonio River (see Figure 3). The trench revealed a sloping rubble-like stone surface on the south face with an upright cedar pole near the middle of the trench (Figure 4). This was topped by the water main encountered in BHT 2. North of the pipe a flat surface of ashlar-dressed limestone was present and formed the north upstream face of the dam. Below this stone was a stone of similar size but roughly dressed. Water began to seep into the trench from a pond adjacent to the site. Excavations on BHT 3 were stopped and cleaning of the profile undertaken.

BHT 4 was excavated between BHT 2 and BHT 3, parallel to BHT 3. We found no trace of the dam in this trench, and the deposits consisted of alluvium (Figure 5). Based on the degree of weathering and the

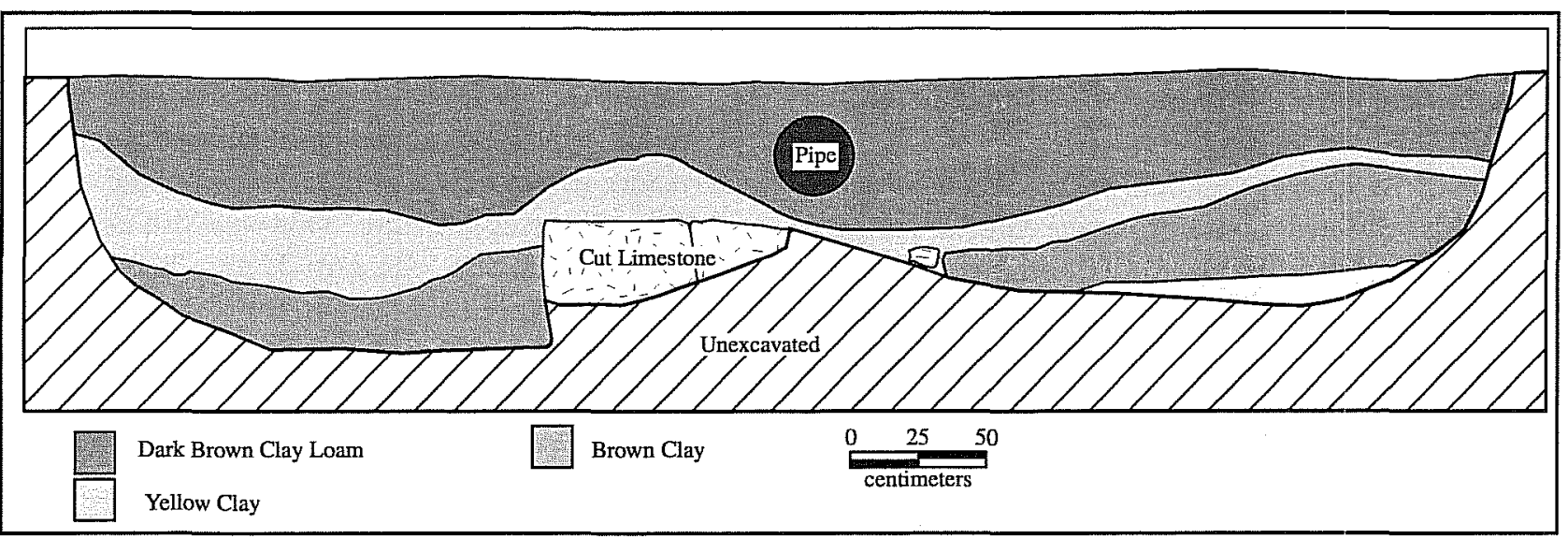

Figure 4. Profile of backhoe trench 3.

Figure 5. Profile of backhoe trench 4.

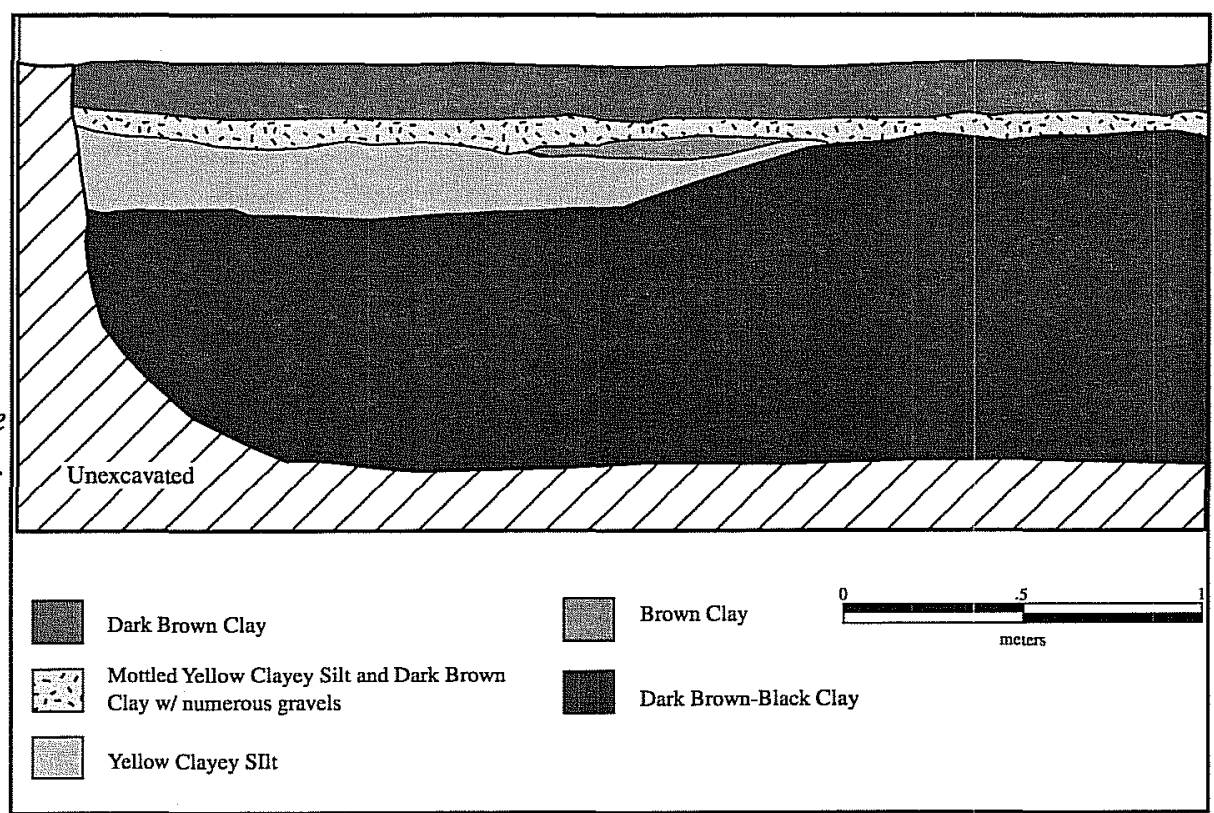


preserved layering, the deposits in BHT 4 appeared to consist of relatively recent deposits.

The backhoe was moved back to the north face of the dam and BHT 5 (Figure 3) was excavated toward the east. The end of the dam was exposed just short of BHT 4. BHT 5 was expanded to the west parallel to the exposed hewn stone. Approximately eight linear meters of the Upper Labor dam were exposed in BHT 5 . The feature is about $1.5 \mathrm{~m}$ wide.

Investigations revealed two distinct episodes of construction (Figures 6 and 7). The lower section of the dam consisted of roughly hewn limestone blocks placed in a low amorphous linear pile. This original component is from the Spanish colonial period. Three vertical cedar posts were also found adjacent to these lower limestone blocks. Although the bottom layer was not entirely exposed, archival documents indicate that the dam ranged between $0.6-2.1 \mathrm{~m}$ in height.

On top of the Spanish Colonial component were neatly cut ashlar-dressed stones from the later-nineteenthcentury dam modification attributed to the city's German masons (Figures 6 and 7). The top of the wall was capped by about a foot of caliche. In addition to the two distinct construction methods, it was noted that the two dams were not set on the same axis.

Evidence suggests that the dam was a wingdam or weir that extended from the western end at the headgate of the acequia and terminated prior to reaching the eastern bank of the river. This arrangement would have served to elevate the level of the containment pool enough to allow flow into the acequia without restricting the normal flow of the Olmos Creek into the river.

\section{Conclusions}

In light of the limited time and resources dedicated to this investigation, it was remarkably successful. All three of the stated objects were met; the exact location and physical boundaries of the Upper Labor dam were established and the Spanish Colonial component was identified. From a conservation standpoint, it was deemed wise to expose only enough of the structure to define its nature without unduly risking further damage by removal of the protective overburden.

From the measurements, it is evident that the exposed structure is comparable to the figures proposed for the dam on August 16, 1762 (page 4). Assuming that the location of the present headgate was correctly reconstructed, the measured end of the structure conforms extremely well with the proposed 29.6-m length. The nature of the contrasting elements in the stonework clearly delineates the Spanish Colonial period from later modifications. This is further confirmed by the difference in the alignment of the two axis. Unlike the other two remaining dams for the San Juan and Espada acequias, both of which have been so heavily modified over the years that the original stonework is not evident, this investigation was able to clearly define the difference between the two periods at the Upper Labor dam.

An additional important point established was that this structure was clearly a weir or wingdam, rather than a full containment structure. This was also established for the existing San Juan dam (Hafernik, et al. 1989). This was a logical adaptation, for it allowed for free flow of the river and spring, while offering protection to the structure during periods of flooding. In light of this finding, the nature of the other dams no longer in existence should be reevaluated.

Unexpectedly, a prehistoric site was discovered during field work. Little is known about this site other than it is buried in an alluvial terrace. If additional work is undertaken that might disturb this site, then further investigations should be conducted to establish the significance of this prehistoric occupation.

Since the structure is well protected by the existing overburden, and its periods of construction and alteration established, no further work is recommended until adequate plans for development have been considered and funding has been acquired. The location and existing partial reconstruction of the structure could lend themselves to an effective display of the nature of the acequia for public education with a minimum of development. 


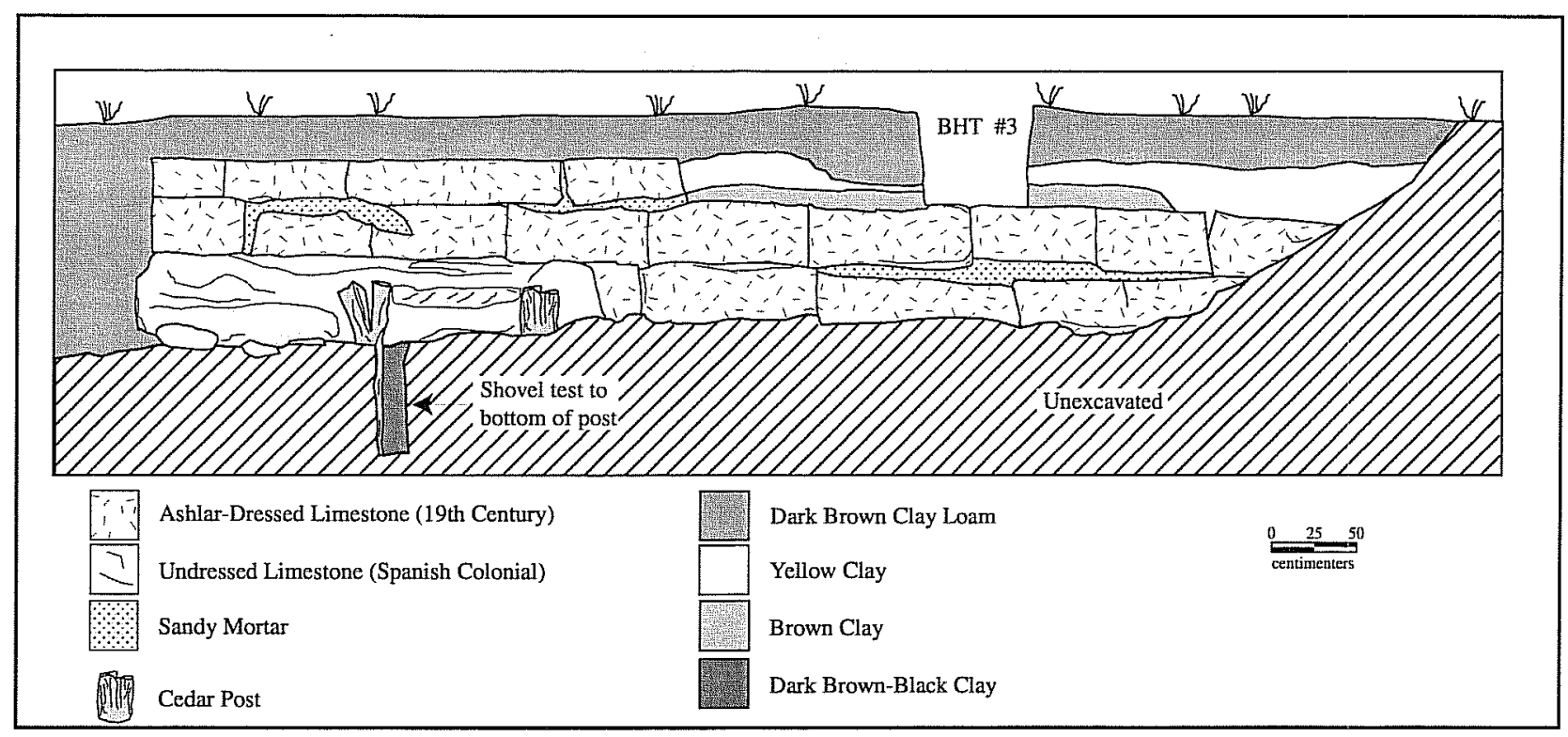

Figure 6. Portion of Upper Labor dam exposed in DHT 5.

Figure 7. Upper Labor dam stonework. Nineteenth century ashler-dressed limestone (upper), undressed Spanish colonial limestone (bottom).

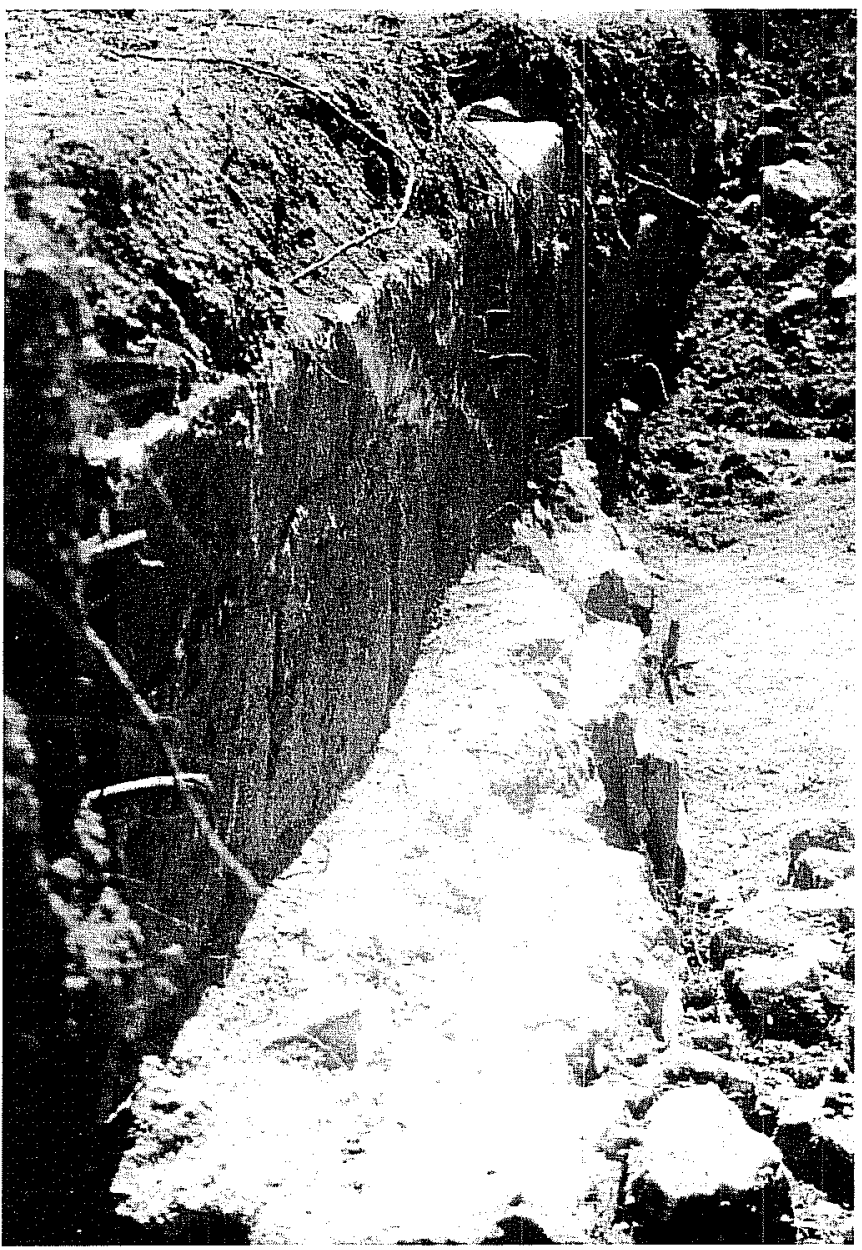




\section{References Cited}

Corner, W.

1890 San Antonio de Bexar, A History and Guide. Bainbridge and Corner, San Antonio.

Castañeda, C. E. (translator)

1926 “A Trip to Texas in 1828: José María Sanchez." Volume 29, The Southwestern Historical Quarterly, Austin.

1936 Our Catholic Heritage in Texas. Vol. 2. Von Boeckman-Jones, Austin.

Chabot, F. C.

1937 With the Makers of San Antonio. Artes Graficas, San Antonio.

Cox, I. W.

1992 Archaeological Monitoring for the Tri-party Improvements Project, San Antonio, Bexar County, Texas. Center for Archaeological Research, The University of Texas at San Antonio, Archaeological Survey Report, No. 204.

de la Teja, J. F.

1995 San Antonio de Béxar: A Community on New Spain's Norther Frontier. University of New Mexico Press, Albuquerque.

Fox, A. A.

1978 Archaeological Investigations of Portions of the San Pedro and Alazan Acequias in San Antonio, Texas. Center for Archaeological Research, The University of Texas at San Antonio, Archaeological Survey Report, No. 49

Fox, A. A. and I. W. Cox

1988 Archaeological Monitoring of the Ashby Street Drainage Project, San Antonio, Bexar County, Texas. Center for Archaeological Research, The University of Texas at San Antonio, Archaeological Survey Report, No. 176.

Gunn, J. D., D. O. Brown, A. A. Fox, A. Frkuska, and D. Watkins III.

1982 Historic and Cultural Landscape Study for the San Antonio Missions. Environmental and Cultural Services, Inc., San Antonio.

Hafernick, D. B., I. W. Cox and A. A. Fox

1989 Archaeological Investigations of the San Juan Dam, 411 BX 266, Bexar County, Texas. Center for Archaeological Research, The University of Texas at San Antonio, Archaeological Survey Report, No. 179.

Hatcher, M. A. (translator)

1919 "Texas in 1820, by Juan Padilla," Volume 23, The Southwestern Historical Quarterly, Austin. 
Labadie, J. H.

1987 An Archaeological and Historical Assessment of the Vista Verde South Project, San Antonio, Texas. Texas. Center for Archaeological Research, The University of Texas at San Antonio, Archaeological Survey Report, No. 156.

Nickels, D. L. And I. W. Cox

1996 An Archaeological Assessment of the Alazán Acequia (41BX620) in the Five Points Area of San Antonio, Bexar County, Texas. Texas. Center for Archaeological Research, The University of Texas at San Antonio, Archaeological Survey Report, No. 253.

Poyo, G. E. (editor)

1996 Tejano Journey, 1770-1850. University of Texas Press, Austin

Ramsdell, C.

1959 San Antonio: A Historical and Pictorial Guide. University of Texas Press, Austin

San Antonio Express,

1872 "Local Affairs," 2 February

1875 "Report of the Public Improvements Committee Upon the Upper Labor Ditch Contract Work," 5 May

1877 "The Grand Celebration" 20 February

1878 "Doings of the City Dads" 10 July 1878

1904 "Hot Tamales From The Garbage Dump," 12 July

"Garbage Dump In Deplorable State," 12 July

"Aldermen Full Of Live Civic Affairs," 26 July

1913 "Famous Floods of Half A Century Ago," December 13

Taylor, F. B., R. B. Hailey, and D. L. Richmond

1966 Soil Survey of Bexar County, Texas. Series 1962 (12), United States Department of Agriculture, Soil Conservation Service.

Tous, G. (translator)

1930 Ramón Expedition: Espinosa's Diary of 1716. Preliminary Studies of the Texas Catholic Historical Society, I(IV). 


\section{Appendix: Backhoe Trench Descriptions}

Backhoe Trench 1

Zone Depth

$1 \quad 0-40 \mathrm{~cm}$

$2 \quad 40-95 \mathrm{~cm}$

$3 \quad 95-150+\mathrm{cm}$

\section{Description}

dark brown 10YR3/3 clay loam, very common roots and rootlets, some small snail shells carbonate filaments below 8 " increase down profile gradual smooth sloping downward medium, subangular, blocky

yellow ish brown 10YR5/2 clay loam

fine, moderate, subangular, blocky with $5 \%$ carbonate filaments abundant roots and rootlets, a few small snail shells between $60-95 \mathrm{~cm}$ clay fill Krontivina

light yellowish brown 10YR6/4

silt loam with less than $1 \%$ carbonate filaments few roots, few snail shell, possible burned rock at $120 \mathrm{~cm}$ fine granular structure

Backhoe Trench 2

\begin{tabular}{|c|c|c|}
\hline Zone & Depth & Description \\
\hline 1 & $0-20 \mathrm{~cm}$ & $\begin{array}{l}\text { very dark grayish brown } 10 \mathrm{YR} 3 / 2 \text { clay loam } \\
\text { medium, moderate, subangular, blocky } \\
\text { common rootlets, few roots } \\
\text { clear smooth lower boundary } \\
\text { modern glass found }\end{array}$ \\
\hline 2 & $20-44 \mathrm{~cm}$ & $\begin{array}{l}\text { yellow ishdark gray } 10 \text { YR } 4 / 1 \text { clay loam } \\
\text { medium, moderate, subangular, blocky } \\
\text { abrupt, irregular and wavy boundary }\end{array}$ \\
\hline 3 & $44-80 \mathrm{~cm}$ & $\begin{array}{l}\text { brown to pale brown } 10 \mathrm{YR} 5.5 / 3 \\
\text { silt loam, } 1 \% \text { dispersed carbonate flecks and filaments } \\
\text { moderate fine granular structure } \\
\text { lower boundary not observed } \\
\text { prehistoric material found in lower zone }\end{array}$ \\
\hline
\end{tabular}


Backhoe Trench 3

\begin{tabular}{|c|c|c|}
\hline Zone & Depth & Description \\
\hline 1 & see profile & $\begin{array}{l}\text { very dark gray } 10 \mathrm{YR} 3 / 1 \text { clay loam } \\
\text { loose with common limestone fragment and clumps of yellow clay } \\
(2.5 \mathrm{Y} 7 / 6) \text { especially on surface } \\
\text { claerly disturbed in areas }\end{array}$ \\
\hline 2 & & $\begin{array}{l}\text { very pale brown }(10 \mathrm{YR} 8 / 4) \text { to } \\
\text { olive yellow }(2.5 \mathrm{Y} 6 / 6) \text { to } \\
\text { yellow }(2.5 \mathrm{Y} 7 / 6) \\
\text { silt to clay loams with dark gray, thin sublayering }\end{array}$ \\
\hline
\end{tabular}

Backhoe Trench 4

\begin{tabular}{|c|c|c|}
\hline Zone & Depth & Description \\
\hline 1 & $0-27 \mathrm{~cm}$ & $\begin{array}{l}\text { dark grayish brown } 10 \mathrm{YR} 3 / 2 \text { clay loam } \\
\text { medium, moderate } \\
\text { clear smooth lower boundary }\end{array}$ \\
\hline 2 & $27-55 \mathrm{~cm}$ & $\begin{array}{l}\text { dark gray } 10 \text { YR } 4 / 1 \text { clay loam } \\
\text { dispersed iron staining } 1 \% \\
\text { fine, moderate } \\
\text { clear smooth lower boundary }\end{array}$ \\
\hline 3 & $55-85 \mathrm{~cm}$ & $\begin{array}{l}\text { dark gray } 10 \mathrm{YR} 3 / 1 \text { clay } \\
\text { common snails } \\
\text { iron staining up to } 3 \% \\
\text { medium, moderate } \\
1 \% \text { calcium carbonate filaments }\end{array}$ \\
\hline 4 & $85-115 \mathrm{~cm}$ & $\begin{array}{l}\text { ver dark grayish brown } 10 \mathrm{YR} 3 / 2 \\
4-5 \% \text { calcium carbonate filaments } \\
5 \% \text { iron staining } \\
\text { medium, fine, moderate }\end{array}$ \\
\hline 5 & $115-135+\mathrm{cm}$ & $\begin{array}{l}10 \mathrm{YR} 2 / 0 \\
5 \% \text { calcium carbonate filaments } \\
\text { fine, moderate }\end{array}$ \\
\hline
\end{tabular}


